\title{
Research on the Path of International Logistics Development in Chongqing Free Trade Zone
}

\author{
Yifei Gong, Jialing $\mathbf{L i}^{*}$ \\ College of Economic and Management, Southwest University, Chongqing, China \\ Email: *gyifei@swu.edu.cn
}

How to cite this paper: Gong, Y. F., \& Li, J. L. (2020). Research on the Path of International Logistics Development in Chongqing Free Trade Zone. Modern Economy, 11, 1053-1063.

https://doi.org/10.4236/me.2020.115079

Received: April 5, 2020

Accepted: May 12, 2020

Published: May 15, 2020

Copyright (อ 2020 by author(s) and Scientific Research Publishing Inc. This work is licensed under the Creative Commons Attribution International License (CC BY 4.0).

http://creativecommons.org/licenses/by/4.0/

\begin{abstract}
As a debugging point of domestic economic development, the free trade zone has pushed China's economic reform and opening up to a new level. With the development of free trade zone, new logistics mode will be created, and new opportunities and challenges will be placed in front of the international logistics of Chongqing Free Trade Zone. Based on the elaboration of the current situation of Chongqing's international logistics development under the new pattern of the free trade zone, this paper establishes the SWOT Analysis Model of the impact of the construction of Chongqing Free Trade Zone on the development of international logistics, and makes an in-depth analysis from four aspects of strengths, weaknesses, opportunities and threats. Finally, it puts forward the path selection to promote the development of Chongqing free trade zone's international logistics in this context.
\end{abstract}

\section{Keywords}

Chongqing Free Trade Zone, International Logistics, SWOT Analysis, Path

\section{Introduction}

The implementation of free trade and relevant preferential policies in Chongqing Free Trade Zone will make the import and export trade more active. This situation puts forward new requirements for international logistics services. First, The Belt and Road (B \& R) has put forward requirements for the development of international logistics in Chongqing. General Secretary Xi Jinping put forward a grand blueprint for building the Silk Road Economic Belt and 21st Century Maritime Silk Road. Chongqing has become an inland hub city. Therefore, it is necessary to realize the connection between domestic distribution and international transportation, transit and distribution. Secondly, the development of Chongqing Free Trade Zone puts forward requirements for its international 
logistics. In order to promote the balanced and rapid development of various regions in the free trade zone, Chongqing will establish an inland international logistics center to promote the adjustment and upgrading of the industrial structure of the free trade zone with the development of international logistics. International logistics for the development of Chongqing Free Trade Zone has become the key to improve the speed and quality of economic growth. Therefore, what is the current situation of the logistics industry in Chongqing Free Trade Zone? What are the advantages, disadvantages, opportunities and threats of free trade zone construction to the development of international logistics? What can free trade zones learn from the logistics development experience of free trade zones at home and abroad? What kind of development path should the international logistics of free trade zone choose? These problems are worth thinking about.

\section{The Current Situation of International Logistics Development in Chongqing Free Trade Zone}

In August 2016, the State Council approved the establishment of Chongqing as a pilot free trade zone. In the past three years, the development of Chongqing's import and export trade has entered the Fast Lane, international logistics has been driven to develop, and the international channels have really opened up. In terms of the open platform of international logistics, Chongqing has built four customs supervision areas: Cuntan bonded port area, Xiyong, Jiangjin and Fuling comprehensive bonded area, and four bonded logistics centers distributed at Chongqing railway, public and water ports. Meanwhile, the establishment of Chongqing International Logistics Group has brought into full play and potential of cooperation between local and foreign cooperation, railway bureau and local cooperation, promoted the interconnection of logistics channels. In terms of opening international logistics channels, to the south, Chongqing opened a new land sea channel rail sea combined transportation train, with freight lines distributed in 201 ports of 84 regions. To the north, Chongqing Manchurian Russia has achieved weekly fixed dispatching, and the channel construction has entered a new era. To the East, Chongqing meticulously builds the golden waterway of the Yangtze River, in the first three quarters of 2019, 147,328,000 tons of waterway freight traffic was completed, an increase of $8.8 \%$ year on year. In addition, air logistics routes are becoming more mature, the Belt and Road has promoted the two-way convergence of passenger flow and logistics.

\section{SWOT Analysis of the Impact of Chongqing Free Trade Zone Construction on the Development of International Logistics}

\subsection{Strengths Analysis}

\subsubsection{Superior Location Conditions}

From the perspective of the territory of China, Chongqing is located in the geometric center, bordering Hubei and Hunan in the East, Guizhou in the south, 
Sichuan in the West and Shanxi in the north, and undertakes the communication and operation between the East and the west, the South and the north. In terms of transportation, Chongqing is the only transportation hub integrating water, land and air transportation in Western China, with superior water transportation conditions. It connects with Shanghai, Nanjing, Han and other cities through the golden waterway of the Yangtze River. Land transportation is also connected with three main railway lines, nine national highways and two expressways, including Chengdu-Chongqing railway, Sichuan-Guizhou railway and Xiangyang-Chongqing Railway. Air logistics routes are also mature. Chongqing Free Trade Zone will also establish an inland international logistics center to enhance the comprehensive competitiveness of international logistics. In the future, it will become the core of international logistics supply chain for multinational enterprises. Therefore, Chongqing can make full use of its location advantages, integrate all kinds of internal and external resources, and further expand the international logistics market.

\subsubsection{Stable Economic Development}

Since the implementation of the western development strategy, Chongqing's economy has maintained a good momentum of sustained and healthy development, initially forming a situation of investment, import and export linkage to promote economic development. At present, Chongqing focuses on the layout of " $6+1$ " pillar industries of automobile and motorcycle, equipment manufacturing industry and natural gas and petrochemical industry, with the top three accounting for $52 \%$, electronic information output value accounting for $18.5 \%$, realizing leapfrog development. At the same time, Chongqing's economic development and foreign trade import and export volume grew rapidly. By 2019, Chongqing's Gross Regional Product (GDP) was 2,360,577 million yuan, with a growth rate of $6.3 \%$, and the total import and export value was 579.278 billion yuan, with a growth rate of $10.92 \%$, see Figure 1 and Figure 2. As the IMF, the world bank, etc. all lowered their forecasts for global economic growth in 2019, in addition, the tension between China and the United States in trade has led to a large downward pressure on the city's investment and import and export, as well as many constraints on the transformation and upgrading of leading industries such as automobiles, which has slowed down the growth of Chongqing's

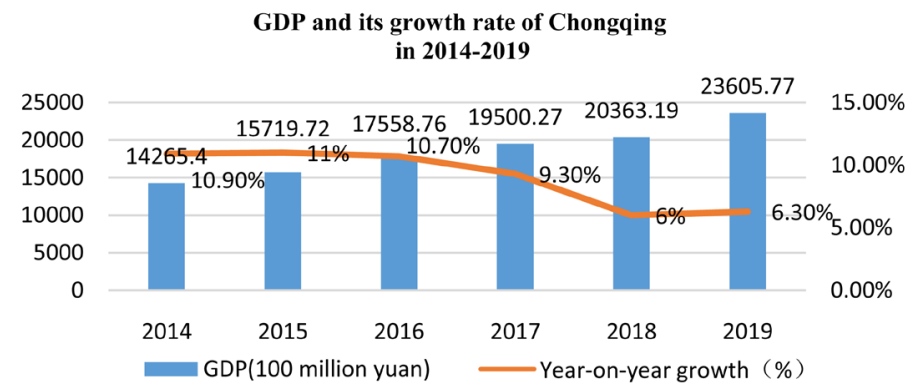

Figure 1. GDP and its growth rate of Chongqing in 2014-2019. Data source: Chongqing statistical information network. 


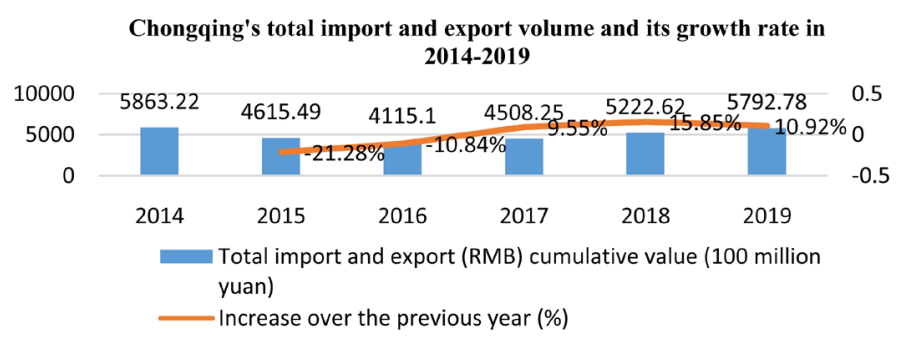

Figure 2. Total import and export volume and its growth rate of Chongqing in 2014-2019. Data source: Chongqing statistical information network.

GDP and import and export in 2019 compared with the historical years. But from the overall analysis, in 2019, Chongqing's economic operation is still in a reasonable range, continuing the overall stable development trend. In the future, Chongqing will play the role of external window and economic radiation to promote the development of Southwest China and the upper reaches of the Yangtze River in accordance with the strategic concept of building "Three Centers, Two Hubs and One Base".

\subsubsection{Innovative System}

Chongqing Free Trade Zone has innovated a number of systems in key areas. By July 2019, it has reported a total of 50 system innovation achievements, including 23 for the first time in China. Among them, with regard to the One Guarantee and Multiple Use management mode implemented at the end of 2018, it is the first to realize the universality of one guarantee text in different business areas, and different guarantee matters in the customs area, namely One Record and Recycling. This series of institutional innovation can not only improve the legal environment of trade, but also enhance the momentum of international logistics development and improve the level of international logistics customs clearance facilitation.

\subsection{Weaknesses Analysis}

\subsubsection{Imperfect Logistics Facilities}

The development of free trade zone has broadened the scope of international logistics services, and the amount of logistics services required is self-evident. The construction of logistics facilities is directly related to all aspects of international logistics development (Zhang, 2015). At present, although Chongqing port attaches importance to the construction of hardware facilities, it does not pay enough attention to the systematic and efficient logistics facilities of international logistics (Zhao, 2017). In addition, the information level among various regions is unbalanced, the functions of freight stations and logistics centers are not perfect, and the layout of logistics facilities is not optimized (Xu, 2016). The backward goods storage facilities and lack of automation equipment lead to relatively low warehousing efficiency. Although the international logistics facilities and the actual operation have been rapid development, but compared with developed areas, there are still many problems, such as the construction level of 
modern high-tech information operation facilities is not enough, the utilization rate of facilities is low.

\subsubsection{The Management Concept of Logistics "Demand Chain" Is Not Strong and the Information Level of Management Is Low}

Generally, foreign enterprises have higher requirements for the effectiveness of logistics. As for Chongqing Free Trade Zone, the same batch of goods may be transported to southwest, northwest, central China and other provinces, so the information management is not timely enough, which will affect the connection of domestic and foreign logistics and transportation points (Zhao, 2017). Therefore, it is necessary to adjust the internal structure of the logistics industry, fully implement the "Demand Chain" management strategy, and meet the domestic and foreign demand for logistics and transportation. From the current situation, there are not many logistics enterprises in Chongqing that can meet the above conditions. In terms of the construction of logistics management information system, its technological process is promoted slowly, and the data resources exchanged are scarce, which is not enough to ensure the full-automatic operation of the whole industry. Many advanced logistics management information technologies, such as barcode technology and GPS technology, have not been widely used in Cuntan port and Fuling port, where traditional transportation and storage are the main businesses.

\subsubsection{Poor Service Quality}

The fundamental of modern logistics industry is the quality of logistics service (Zhang, 2018). In logistics transportation, not only ordinary goods are required to be transported, but also advanced storage technology and rapid logistics speed are required. In addition, The development of international trade in the free trade zone has made the scope of logistics no longer limited to a small range of domestic services, but also a large range of international services, which not only requires one-stop non transit services, but also requires accurate analysis of the international situation to improve the quality and standard of services. However, the transition of Chongqing logistics enterprises relies on the economic benefits brought by goods transportation and storage services, neglecting the added value of service quality brought by circulation processing and value-added services, and the improvement of service quality is slow, which will seriously hinder the development of international logistics.

\subsection{Opportunities Analysis}

\subsubsection{Favorable Supportive Policy}

In terms of tax policies, the State Administration of Taxation has stipulated that enterprises or individual shareholders registered in the pilot area can pay income tax in installments within a period of no more than five years, which shows that the free trade area has absolute preferential treatment in tax. The cancellation of some trade restrictions and convenient import and export customs clearance policies will speed up the flow of materials inside and outside the free trade zone, 
and the resulting logistics volume will also increase significantly. Since November 1, 2019, the first local regulation of Chongqing Free Trade Zone, regulations of China (Chongqing) pilot Free Trade Zone, has been officially implemented. This regulation has planned the construction of Chongqing pilot Free Trade Zone, strengthened responsibility and boosted confidence. In addition, relevant departments or institutions in Chongqing have also issued a series of free trade zone promotion policies, which indirectly provide more impetus for the development of international logistics.

\subsubsection{Convenient Trade Environment}

The construction of Chongqing Free Trade Zone provides convenient conditions for the integration of international logistics. The construction of it provides convenient conditions for the integration of international logistics. It not only improves China's position in the global trade value chain, but also promotes the upgrading of water, land and air transportation industry. Under the background that the State encourages enterprises to Go Out, the supervision mode of the free trade zone also makes trade more free, which leads to the increase of material flow. As a supply chain integration platform, the free trade zone enables the logistics enterprises in the free trade zone to go abroad more easily and carry out various transnational businesses better with the advantage of resources.

\subsection{Threats Analysis}

\subsubsection{The Radiation Driving Role of Regional Logistics Needs to be Played}

At present, there are differences in the logistics environment in Chongqing Free Trade Zone, coupled with different logistics systems, which do not form a unified logistics channel and service network, affecting the regional radiation driving role. At the same time, due to the neglect of port demand and the lack of overall planning when connecting the comprehensive transportation system, the function of the shipping center in the upper reaches of the Yangtze River is affected. The layout of inland hinterland and overseas logistics has not been fully considered, nor has the free trade venue become an international trade system radiating from home and abroad.

\subsubsection{Relevant Laws and Regulations of International Logistics Are Not Perfect}

The construction of free trade zone promotes the increasingly close relationship between logistics, so the revision and improvement of relevant laws and regulations on international transportation and storage should be taken into account. At present, most of the laws are formulated and used in the old economic system, and some of them can no longer meet the needs of the development of modern logistics. International logistics industry is a new industry, its business functions have exceeded the scope that these laws and regulations can adjust, new problems need new methods. The laws and regulations related to international logistics are not perfect enough, which leads to huge legal and regulatory 
challenges for the free trade zone logistics.

\subsubsection{Lack of International Logistics Professionals}

In the process of international logistics operation, it involves business, finance, customs, railway transportation, etc. The construction of free trade zone will lead to the increase of post demand in international logistics and related links. If Chongqing Free Trade Zone wants to develop into an inland international logistics center, it needs more logistics talents with rich logistics theoretical knowledge, practical operation experience and broad international vision. But now, Chongqing's logistics talents are not only in short supply, but also the knowledge reserve of the existing talents cannot meet the needs of the international logistics, which leads to the development progress of international logistics cannot keep up with the development needs.

According to the strengths, weaknesses, opportunities and threats of the logistics development of Chongqing Free Trade Zone analyzed above, the strategic analysis matrix of the logistics development of Chongqing Free Trade Zone is obtained (see Table 1). The fifth part will discuss the Countermeasures of Chongqing Free Trade Zone International logistics development according to this analysis matrix.

Table 1. SWOT analysis of international logistics development in Chongqing Free Trade Zone.

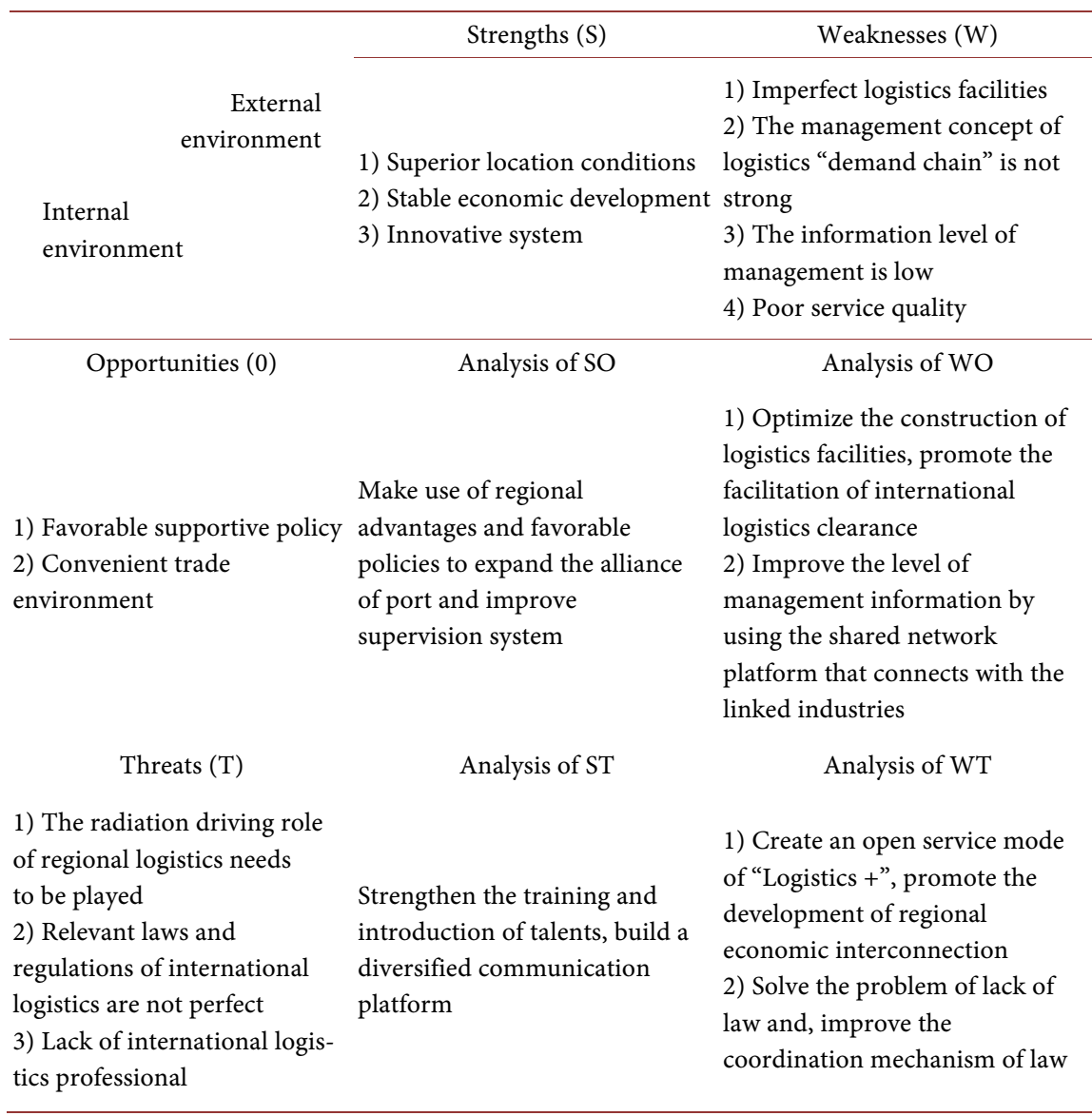




\section{The Path Choice of International Logistics Development in Chongqing Free Trade Zone}

\subsection{SO Type Strategic Path-Expand the Alliance of Port, Improve Supervision System}

Chongqing Free Trade Zone is an important node and important transportation hub of various strategies. The development of its port transportation will have a profound impact on other industries. Therefore, it is necessary to coordinate and manage all sub ports and logistics companies in the city, establish the alliance of port, and share information at any time, improve the efficiency of logistics management and transportation, so as to keep up with the pace of international logistics under the new situation. In addition, the government should give full play to the role of manager and guide to the logistics industry. Not only that, but also deepening the reform of regulatory system. It should introduce foreign management mode and experience, and build a policy system adapted to the characteristics of international logistics, so as to improve the construction of the supervision system.

\subsection{WO Type Strategic Path (1)-Optimize the Construction of Logistics Facilities, Promote the Facilitation of International Logistics Clearance}

Facing the rapid development of logistics technology, the relatively backward development of logistics facilities will affect the further development of international logistics, so it is necessary to have advanced infrastructure as the premise. On the one hand, the free trade zone can refer to the advanced infrastructure at home and abroad to improve the infrastructure of goods storage and distribution, build an international express supervision center to further improve the construction of automation and information facilities. For problems such as waste and shortage of logistics facilities, infrastructure sharing is implemented to form a regional logistics system, so as to reduce the cost and investment pressure of logistics enterprises (Ackermann \& Muller, 2005). On the other hand, the logistics enterprises should based on a active strategy of opening up to the outside world, strengthen the cooperation of cross departmental and cross regional inland coastal customs clearance, make the relevant departments of port management supervise each other, share information, and jointly enforce the law, deepen the reform of large-scale customs clearance, and improve the efficiency of customs clearance to promote the facilitation of international logistics customs clearance (Tong et al., 2017).

\subsection{Wo Type Strategic Path (2)-Establish a Shared Network Platform, Improve the Level of Management Information}

The establishment of logistics information sharing network system is the foundation and premise of open market supervision system. On the one hand, it can connect the network system of aviation, railway, aviation and seaport; on the other hand, it can contact with the information system of tax, customs, com- 
modity inspection and other fields to provide some basic and social information for the international logistics industry (Tong et al., 2017). Secondly, it can effectively match the processes of procurement, production, sales and other links, standardize the sub information platform interface and logistics sharing information service platform, promote the application of information technology in the field of international logistics, and improve the management information level of commercial products. Finally, through the integration of big data, cloud computing and other information technologies, the information of different departments will be collated, consolidated and disclosed, which will not only help to enhance the transparency of management information, but also help to improve the efficiency of supervision in the event.

\subsection{ST Type Strategic Path-Strengthen the Training and Introduction of Talents, Build a Diversified Communication Platform}

Facing the shortage of international logistics talents, the free trade zone needs to establish its own talent training system. In accordance with the principle of delivering students to their counterparts, colleges and universities can focus on training a number of technical talents, management talents and high-quality leading talents in the field of logistics, especially in the field of international logistics, by means of order training, directional training and entrusted training (Wang, 2018). In addition, establish the training base for international logistics practitioners and strengthen the cultivation of students' transnational team spirit and international convention and regulation literacy in terms of professional literacy (Weng \& Chen, 2018). In terms of talent introduction and communication platform construction, first of all, logistics enterprises in the free trade zone should introduce overseas talents from policies and funds, such as preferential policies on housing, medical treatment, loans, etc., and establish an effective incentive and restriction mechanism. Secondly, relevant organizations should build a diversified exchange platform, and then invite experts to carry out education and training, improve the enthusiasm of enterprises and employees to participate in international logistics training, and make full use of outstanding talents.

\subsection{WT Type Strategic Path (1)-Create an Open Service Mode of "Logistics +", Promote the Development of Regional Economic Interconnection}

Logistics enterprises need to change a single logistics service mode and provide different value-added services of goods, so as to meet the diversified needs of customers, provide safety and maintenance services for customers. It should integrate the four elements of supply chain, namely, business flow, logistics, capital flow and information flow, closely integrate logistics with trade, finance and production, and create a "logistics plus" service model. For example, the implementation of the mode of "Internet plus logistics + finance" has realized the in- 
formation supply chain informatization in the aspects of product distribution and customer service through the advantages of the Internet. Therefore, Chongqing should seize this opportunity, not only to consolidate the industrial development foundation, promote the effective allocation of resources, but also rely on industrial agglomeration, strengthen logistics supporting, extend supply chain services, promote the linkage and integration of manufacturing industry, commerce and trade industry and logistics industry, so as to promote the development of regional economic interconnection.

\subsection{WT Type Strategic Path (2)-Solve the Problem of Lack of Law, Improve the Coordination Mechanism of Law}

First of all, relevant departments should solve the problem of lack of legislation. It is necessary to formulate management regulations and laws that are suitable for the characteristics of international logistics in the free trade zone, such as laws and regulations on international maritime cargo transport, international air cargo transport, railway cargo transport, etc. At the same time, it is also necessary to formulate standards and specifications for international transport of goods, regulations related to means of transport, etc. Secondly, it is necessary to reasonably coordinate the legal application mechanism, clarify the jurisdiction scope of enterprises with dual identities inside and outside the zone, and specify the legal restrictions on such enterprises, so as to have legal basis in case of problems and ensure the applicability. In particular, it should be based on the relevant domestic laws, in accordance with international practices and for reference or accede to appropriate international conventions.

\section{Conclusion}

The establishment of Chongqing Free Trade Zone has brought immediate results to international logistics by virtue of its reform dividend. Moreover, with its regional advantages, favorable policies and convenient terms of trade, the free trade zone can promote the gradual formation and expansion of logistics network. As Chongqing Free Trade Zone has just started, many policy effects have not been shown, but the development of international logistics is an inevitable requirement for the establishment of it. Therefore, Chongqing should face up to the current situation, opportunities and challenges of its own international logistics development, and make efforts to promote the long-term and stable development of international logistics from the following aspects: optimizing the construction of logistics facilities, promoting the facilitation of international logistics customs clearance; establishing an interconnected shared network platform, improving the level of management information; expanding the port alliance, improving the regulatory system; strengthening the training and introduction of talents, building a diversified communication platform; solving the problem of lack of law, improving the legal coordination mechanism; creating an open service mode of "Logistics +", promoting the development of regional 
economic interconnection.

There are still some shortcomings in this paper. First of all, due to the short establishment time of Chongqing Free Trade Zone, the relevant information and statistical data are not very complete. With the development of it, the information and data will continue to improve in the follow-up research, and the data used for empirical analysis will become more and more accurate. Secondly, the international logistics integrates many internal factors, such as strengths, weaknesses, opportunities and threats, and the relationship among them is very complex. Therefore, in the follow-up study, the factors that cannot be involved in this study can also be put into the category of research.

\section{Supported}

Supported by 2016 Social Science Planning and Cultivation Project Research "on the Development Mode and Path of Inland International Logistics Center under the Framework of Chongqing Free Trade Zone, (2016PY42)" and the Central University Basic Research Business Expense Project (SWU1909314).

\section{Conflicts of Interest}

The authors declare no conflicts of interest regarding the publication of this paper.

\section{References}

Ackermann, J., \& Muller, E. (2005). Modeling, Planning and Designing of Logistics Structures of Regional Competence-Cell-Based Networks with Structures Types. Robotics and Computer-Integrated Manufacturing, 6-14.

Tong, X. S., Li, Z. W., \& Tong, Z. X. (2017). Study on the Development Path of Logistics Industry in Henan Free Trade Zone. Logistics Engineering and Management, No. 8, 20-24.

Wang, L. G. (2018). Strategic Study on the Development of Modern Local Logistics Industry in the Context of the Xiangyang Free Trade Zone. Modern Business Trade Industry, No. 34, 22-23.

Weng, Q. W., \& Chen, C. L. (2018). Research on Training Mode of Applied Logistics Talents under the Background of Hainan Free Trade Zone. Modern Economic Information, No. 18, 389-390.

Xu, G. (2016). New Trend of Logistics and Supply Chain Development under Free Trade Zone. Market Modernization, No. 27, 91-92.

Zhang, B. (2018). Research on Logistics Development Model of Shanghai Free Trade Zone. Dalian: Dalian Maritime University.

Zhang, X. Y. (2015). The Impact of Shanghai Free Trade Zone on the Development of Logistics Industry. E-Business Journal, No. 12, 21-22.

Zhao, Z. M. (2017). Analysis of Chongqing Port Logistics Development under "The Belt and Road" Strategy. Market Modernization, No. 24, 40-41. 